https://doi.org/10.17816/MAJ191S1194-196

\title{
COMBINED ACTION OF ANTIMICROBIAL PEPTIDES AND NONIONIC SURFACTANTS TOWARDS BACTERIA
}

\author{
M.S. Zharkova ${ }^{1}$, D.S. Orlov ${ }^{1}$, A.A. Kolobov', O.V. Shamova ${ }^{1}$ \\ ${ }^{1}$ Institute of Experimental Medicine, Saint Petersburg, Russia; \\ ${ }^{2}$ State Research Institute of Highly Pure Biopreparations, Saint Petersburg, Russia

\section{СОЧЕТАННОЕ ДЕЙСТВИЕ АНТИМИКРОБНЫХ ПЕПТИДОВ И НЕИОНОГЕННЫХ ПОВЕРХНОСТНО-АКТИВНЫХ ВЕЩЕСТВ В ОТНОШЕНИИ БАКТЕРИЙ}

\author{
М.С. Жаркова ${ }^{1}$, Д.С. Орлов ${ }^{1}$, А.А. Колобов ${ }^{2}$, О.В. Шамова ${ }^{1}$ \\ ${ }^{1}$ ФГБНУ «Институт экспериментальной медицины», Санкт-Петербург; \\ ${ }^{2}$ ФГУП «Государственный научно-исследовательский институт особо чистых биопрепаратов» \\ ФМБА России, Санкт-Петербург
}

Antimicrobial peptides (AMPs) have certain resemblance with surfactants. Using checkerboard titrations and spectrophotometrical analysis of the membrane permeability for chromogenic markers, we found that nonionic surfactants "Tritons" significantly increase the speed of membranolytic action of AMPs, and enhance their antibacterial activity.

Keywords: antimicrobial peptides; Triton X; synergy; antibacterial action; membrane permeabilization.

Антимикробные пептиды имеют определенное сходство с поверхностно активными веществами (ПАВ). Методом серийных разведений по схеме «шахматной доски» и путем спектрофотометрического анализа проницаемости мембран для хромогенных маркеров было установлено, что неионогенные ПАВ «Тритоны» существенно ускоряют мембранолитическое действие АМП и повышают их антибактериальную активность.

Ключевые слова: антимикробные пептиды; тритон X; синергизм; антибактериальное действие; проницаемость мембран.

Introduction. AMPs of innate immunity provide a broad spectrum of antimicrobial and immunomodulatory effects. By their amphipathic structure and the mode of interaction with lipid membranes AMPs resemble surfactants. It is of interest to analyze their combined action with other such molecules. Surfactants are widely presented in nature, industry and everyday life, serving as detergents, emulsifiers, dispersing, foaming and wetting agents, and being components of cleansers, disinfectants, cosmetics, etc. We investigated the action of AMPs porcine protegrin 1 (PG-1) and caprine bactenecin with molecular mass of $3.4 \mathrm{kDa}$ (ChBac3.4) in combinations with nonionic surfactants of the "Triton X" group against bacterial cells and their membranes. Tritons are copolymers of 4-tert-octylphenol (hydrophobic part) and ethylene oxide residues (EORs) (hydrophilic part). Members of the group differ in the number of EORs per molecule.

Material and methods. $\mathrm{ChBac} 3.4$ was chemically synthesized by Dr. A. Kolobov (State Research Institute of Highly Pure Biopreparations, Saint Petersburg, Russia). Synthetic PG-1 was kindly provided by Prof. R. Lehrer (University of California, Los Angeles). Detergents of "Triton X" series were purchased from Sigma-Aldrich, USA.

Antibacterial activity was determined by serial dilution assay with slight modifications proposed for AMPs [1]. Microplates were preincubated with $0.1 \%$ BSA for $1 \mathrm{~h}$ at $37^{\circ} \mathrm{C}$ to minimize a nonspecific binding of AMPs to the wells. 2.1\% MüllerHinton broth was used as a growth medium.

Combined antibacterial action was assessed by checkerboard titrations [2], and fractional inhibitory concentration indices (FICIs) were calculated: $\mathrm{FICI}=[\mathrm{A}] / \mathrm{MIC}_{\mathrm{A}}+[\mathrm{B}] / \mathrm{MIC}_{\mathrm{B}}$. $\mathrm{MIC}_{\mathrm{A}}$ and $\mathrm{MIC}_{\mathrm{B}}$ are the minimal inhibitory concentrations (MICs) of substances $\mathrm{A}$ and $\mathrm{B}$ alone; $[\mathrm{A}]$ and $[\mathrm{B}]$ are the concentrations of $\mathrm{A}$ and $\mathrm{B}$ in combination. Minimal FICI $\leqslant 0.5$ indicated synergy; $0.5<$ FICI $\leqslant 1.0-$ additivity; $1.0<$ FICI $\leqslant 2.0$ - independent action, FICI $>2.0-$ antagonism.

We analyzed the effect of the substances and their combinations on the permeability of $E$. coli ML-35p membranes for chromogenic markers [3]. ONPG (o-nitrophenyl- $\beta$-D-galactoside, a substrate of cytoplasmic $\beta$-galactosidase) and nitrocefin (a substrate of periplasmic $\beta$-lactamase) were used to investigate damaging of inner and outer membranes, accordingly. The markers penetrate to the enzymes which split them only if corresponding membranes are damaged. Colored products of the cleavage were detected at $420 \mathrm{~nm}$ and $486 \mathrm{~nm}$, respectively. Optical density (OD) was measured on a plate spectrophotometer 1 time per minute at $37^{\circ} \mathrm{C}$ with shaking, starting immediately after adding the bacteria. Plate wells contained $10 \mathrm{mM}$ 
Antimicrobial action of AMPs alone and in combination with Tritons

\begin{tabular}{|l|l|c|c|c|c|}
\hline \multirow{2}{*}{ Bacteria } & \multicolumn{2}{|c|}{ AMPs } & \multirow{2}{*}{ MIC $(\mu \mathrm{M})$} & \multicolumn{3}{c|}{ Minimal FICl in combination with Triton } \\
\cline { 4 - 6 } & & & $\mathrm{X}-45$ & $\mathrm{X}-114$ & $\mathrm{X}-405$ \\
\hline \multirow{2}{*}{$\begin{array}{l}\text { E.coli } \\
\text { ML-35p }\end{array}$} & $\mathrm{PG}-1$ & 3.1 & 0.25 & 0.25 & 0.5 \\
\cline { 2 - 6 } & ChBac3.4 & 3.1 & 0.375 & 0.375 & 0.75 \\
\hline $\begin{array}{l}\text { P. aeruginosa } \\
\text { ATCC 27853 }\end{array}$ & PG-1 & 0.12 & 0.25 & 0.25 & 0.25 \\
\cline { 2 - 6 } & ChBac3.4 & 1.6 & 0.375 & 0.375 & 0.375 \\
\hline $\begin{array}{l}\text { S. aureus } \\
\text { SG511 }\end{array}$ & PG-1 & 0.05 & 0.25 & 0.25 & 0.25 \\
\cline { 2 - 6 } & ChBac3.4 & 3.1 & 0.375 & 0.25 & 0.5 \\
\hline
\end{tabular}
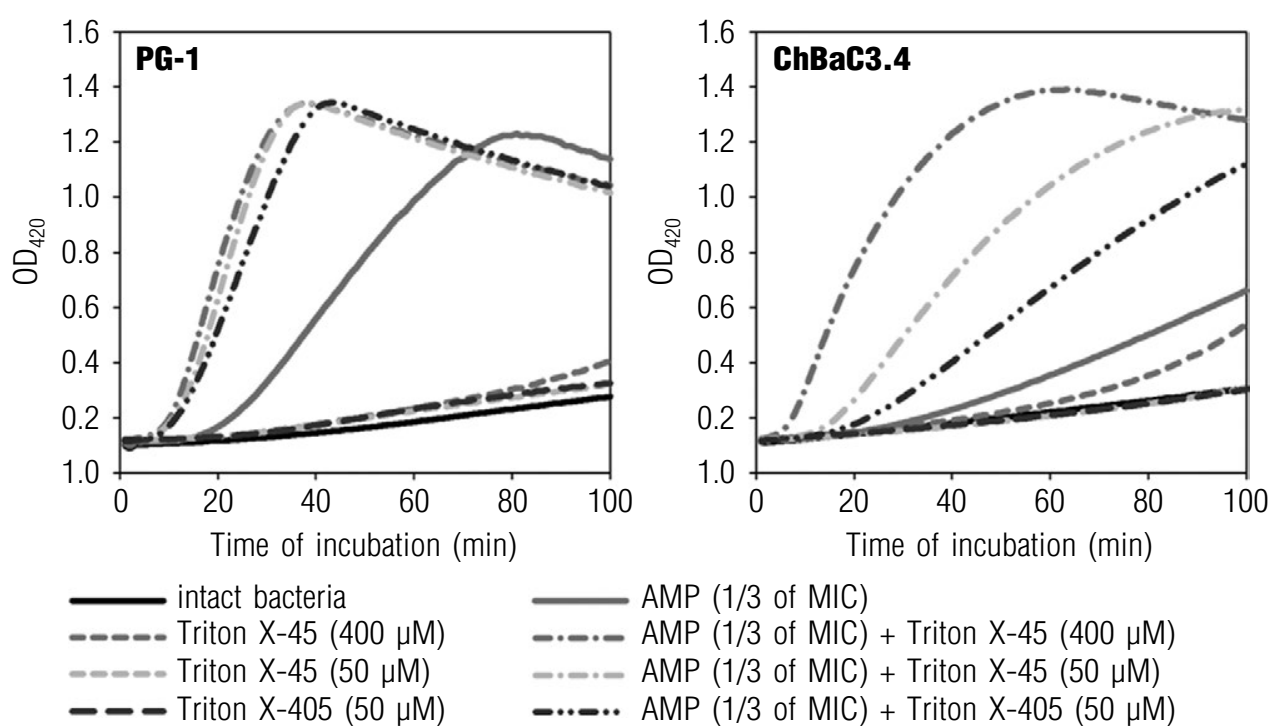

$$
\begin{aligned}
& \begin{array}{l}
\text { AMP (1/3 of MIC) } \\
\text { AMP (1/3 of MIC) + Triton X-45 (400 } \mu \mathrm{M})
\end{array} \\
& \text { - - AMP (1/3 of MIC) + Triton X-45 (50 } \mu \mathrm{M})
\end{aligned}
$$

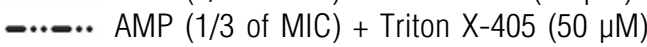

Fig. 1. Kinetics of the inner membrane permeability of $E$. coli ML-35p for the chromogenic marker ONPG under the combined action of PG-1 (left) or ChBac3.4 (right) with Tritons X-45 and X-405

sodium phosphate buffer $\mathrm{pH} 7.4,100 \mu \mathrm{M} \mathrm{NaCl}$, $2.5 \cdot 10^{7} \mathrm{CFU}$ of washed, stationary-phase $E$. coli ML-35p, the substances of interest or an equivalent volume of buffer, and the marker $(20 \mu \mathrm{M}$ nitrocefin or $2.5 \mathrm{mM}$ ONPG).

Results and discussion. MIC of Triton X-45 (4-5 EORs) against S.aureus was $100 \mu \mathrm{M}$. MIC of Triton X-114 (7-8 EORs) against $S$. aureus and $P$. aeruginosa was $400 \mu \mathrm{M}$. In other cases tested Tritons (X-45, X-114, X-102, X-165, X-305, $X-405)$ had no antibacterial effect in concentrations no higher than $400 \mu \mathrm{M}$; corresponding MICs were assumed to be $800 \mu \mathrm{M}$ for further calculations. Tritons $\mathrm{X}-45$ and $\mathrm{X}-114$, as well as Triton $\mathrm{X}-405$, that has the longest hydrophilic tail of 35 EORs, were further tested in combinations with AMPs. MICs of AMPs and their minimal FICIs with Tritons are summarized in table 1 (as medians of 3 independent experiments). Pronounced synergistic effects were observed against all tested microorganisms $(\mathrm{FICI} \leqslant 0.5)$.

Examples of the curves illustrating the influence of substances on the permeability of the inner membrane of $E$. coli ML-35p are shown at
Fig. 1. For the outer membrane the dependencies were less prominent, but the same. The presence of both low and high (Fig. 1) concentrations of Tritons accelerated the damaging action of AMPs on the bacterial membranes. Higher concentrations caused more pronounced effect. Shorter Tritons were more effective than those with a massive hydrophilic part. However, Tritons have not exhibited a membranolytic action individually, at least during the first 1.5 hours (Fig. 1), and when the AMP in the mixture was deficient (1/12 of MIC of AMPs produced no noticeable membranolytic effect by itself), the difference between Tritons alone and in combination with AMPs (in concentration of $1 / 12$ of MIC) was not observed (not shown at Fig. 1). It can be concluded that AMP is the agent that initiates the damage to bacterial membranes in such combinations.

Thus, nonionic surfactants can enhance membranolytic activity of AMPs and significantly potentiate their action against both gram-positive and gram-negative bacteria.

The work was supported by RFBR grant No. 18-315-00333. 


\section{References}

1. Antibacterial peptide protocols / W. Shafer (ed.). Totowa, NJ: Humana Press Inc., 1998. 255 p.

2. Orhan G, et al. Synergy Tests by E Test and Checkerboard Methods of Antimicrobial Combinations against Brucella melitensis. J. Clin. Microbiol. 2005;43(1):140-143.

3. Lehrer R, et al. Concurrent assessment of inner and outer membrane permeabilization and bacteriolysis in E. coli by multiple-wavelength spectrophotometry. J. Immunol. Methods. 1988;108:153-158. 